\title{
Breast Feeding Pattern may be Associated with Persistent Low Back Pain and Pelvic Pain Half a Year Postpartum
}

\author{
Ingrid Margareta Mogren
}

Department of Clinical Science, Obstetrics and Gynecology, Umeå University, Sweden

\begin{abstract}
Objective: The aim of this study was to investigate the history of oral and current contraception use, age at menarche, smoking, and breast feeding in relation to remission or persistence of low back pain and pelvic pain (LBPP) six months after delivery.

Materials and Methodology: This study was a follow-up study of 639 women who reported LBPP during pregnancy. The respondents were divided into three groups: 'no pain', 'recurrent pain', and 'continuous pain'.

Results: In total $96 \%$ had breast fed to some degree after delivery. Current full-time breast feeding was associated with an increased risk $(\mathrm{OR}=2.8)$ of continuous pain (LBPP) six months after delivery. Women with continuous pain had also a significantly longer total period of breast feeding in relation to women with remission of pain $(\mathrm{p}=0.035)$.

Conclusion: Full-time breast feeding and longer period of breast feeding were positively associated with persistent low back and pelvic pain six months after delivery.
\end{abstract}

\section{INTRODUCTION}

\section{Low Back and Pelvic Pain}

Low back pain and pelvic pain (LBPP) during pregnancy is a common clinical problem with an extremely high (85$94 \%$ ) risk of recurrence during a subsequent pregnancy [16]. Although remission occurs after delivery, around 4 out of 10 women still have some degree of symptoms six months after delivery [7-11]. Postpartum back pain has been reported as considerably hampering movement-related activities in the short term, and even at three years postpartum, $20 \%$ of all women with back pain during pregnancy report persistent symptoms $[12,13]$.

The aetiology of the condition is poorly understood and there is still no consensus on the definition of pelvic pain during pregnancy [14]. A general increase in the mobility of joints during pregnancy has been described [15] and an increased spinal load, larger fetal weight, and decreased stability in the pelvic girdle have been proposed as major causes $[14,16]$. Further, changes in perception of movement and movement coordination have also been observed, thus indicating muscle dysfunction [14]. A recent study investigating postpartum pelvic pain ('pelvic joint syndrome') finds no difference between cases and their controls for procedures such as MRI, X-ray, blood or urine analysis [17]. However, clinical examination revealed significant differences with regard to provocative tests and tenderness in the muscles and ligaments of the low back and pelvis [17].

*Address correspondence to this author at the Department of Clinical Science, Obstetrics and Gynecology, Umeå University, S - 90187 Umeå, Sweden; Tel: +46-90-7852146; Fax: +46-90-77 39 05;

E-mail: ingrid.mogren@obgyn.umu.se

\section{Breast Feeding}

During the 20th century there was a global decline in breast feeding and at its lowest, the rate of breast feeding in Sweden was estimated to be around $30 \%$ of mothers at the beginning of the 1970s [18]. The Baby Friendly Hospitals Initiative, a global campaign organized by UNICEF with the aim of encouraging breast feeding, was introduced in Sweden in 1993 [18]. The breast feeding rate subsequently increased from around $50 \%$ to $73 \%$ during the following four years [18]. In 2000, the breast feeding rates in Sweden at 1 week, 4 months and 6 months were $92.5 \%, 83.2 \%$ and $72.2 \%$ respectively [18]. Smoking and supplementation without medical reasons influence the duration of breast feeding negatively, however, parity has no significant influence [19].

Breast feeding is associated with short-term positive health effects in the offspring such as nutritional status and growth as well as long-term health effects such as taller stature, reduce the incidence of immune related diseases, reduced risk of atherosclerosis later in life and potentially a reduction in diastolic blood flow [20-24]. Lactation is also associated with a decreased risk of breast and ovarian cancer for women who have breast fed [21, 25]. Among clinicians, the effect of lactation has been discussed as possibly being associated with impaired remission of LBPP, however, there are no published studies on this issue.

\section{Oral Contraception (OC) and Menarche}

The possible significance of pre-pregnancy OC use and LBPP during pregnancy has long been debated. Although no association has been found among female athletes, shortterm users of OC have been reported to have an increased risk for persistent back pain after delivery in relation to long- 
term users $[26,27]$. An increased risk of back pain during pregnancy among OC users has been reported, but then other results have not supported an association between use of OC and risk of low back pain and pelvic pain during pregnancy $[6,28]$.

There are few studies investigating the possible association between menarche and persistent pelvic pain after parturition. A Norwegian study has found women with persistent pelvic pain and pelvic joint instability had a significantly lower age at menarche, whilst menarche was not associated with risk of low back pain and pelvic pain during pregnancy $[6,29]$. In a recent review on factors predisposing women to chronic pelvic pain, early menarche was found to be associated with dysmenorrhoea and dyspareunia, but not with noncyclical pelvic pain [30].

It is believed that there are currently no publications on the major part of the research questions investigated.

The aim of the study was to investigate the history of oral and current contraception use, age at menarche, smoking, and breast feeding in relation to remission or persistence of LBPP six months after delivery. The main hypothesis tested was that previous or current exposition of endogenous or exogenous hormones, such as estrogens, gestagens and prolactin, may influence the risk of persistent LBPP up to six months post partum.

\section{MATERIALS AND METHODOLOGY}

The current study is a continuation of a previous study where all women who delivered within a specific time frame in the Departments of Obstetrics and Gynecology at Umeå University Hospital, Västerbotten (UUH), and the Sunderby Hospital, Norrbotten (SH) in northern Sweden were invited to complete a questionnaire (questionnaire $1=\mathrm{Q} 1$ ) on their obstetric and gynaecological history, actual pregnancy and delivery [6]. The first date of inclusion (i.e. the date of delivery) was 1 January 2002 and the last date was, 30 April 2002 at both departments. The women received verbal and written information of the aims of the study from a midwife on duty at the department within usually 24 hours of the delivery. The study was approved by the Ethics Committee at the Umeå University (Dnr. 01-335).

During the period of 1 January 2002 to 30 April 2002, the total number of women who delivered at the UUH and SH was 1,114 with $516(46.3 \%)$ delivering at UUH and 598 women $(53.7 \%)$ at the SH. For inclusion in the study, the women had to have reached a gestational age of at least 23 weeks, ending in a live birth or a stillbirth. Another inclusion criterion was competence in the Swedish language, which decreased the number of eligible women to 1,071 . Women who agreed to participate received a questionnaire with a unique number. The identification number of the women who declined participation was likewise recorded, for analysis of missing data. Non-respondents were women who either did not receive a questionnaire or did not complete the questionnaire they were given. The net sample consisted of 891 respondents (Q1) and the response rate was therefore $83.2 \%(891 / 1,071)$. Place of delivery did not influence risk in the logistic regression analyses. Detailed information on the sample has been presented in a previous paper [6]. The study used a cross-sectional design.
Women reporting LBPP $(\mathrm{n}=639)$ during pregnancy $(\mathrm{Q} 1)$ were followed up with a second questionnaire (Q2) approximately six months after delivery, thus constituting a cohort. Only women reporting LBPP during pregnancy were followed up because pregnancy-related LBPP only arises during pregnancy and the current study investigated factors related to remission or persistence of pregnancy-related LBPP post partum. The questionnaire consisted of 39 questions on issues such as LBPP after pregnancy, use of medical services, family situation, perceived health, sick leave, sex life, physical activities, oral contraception (OC) and breast feeding. One, or if required, several reminders were sent to the subjects if no response was received for the Q2. Altogether $77.0 \%(492 / 639)$ of eligible subjects responded to the Q2. Twenty-eight women were excluded because they completed the questionnaire 9 months or more after date of delivery. The net sample therefore comprised 464 (72.6\%) women who responded to the Q2.

\section{Definitions}

Low back pain or pelvic pain during pregnancy (LBPP) in the previous study $(\mathrm{Q} 1)$ was defined as 'recurrent or continuous pain for more than 1 week from the lumbar spine or pelvis' during recent pregnancy. A woman was considered to have LBPP during pregnancy if she answered the specific question on localization of pain in the affirmative, which included marking the affected area on a drawing included in the questionnaire [6].

Actual low back pain and pelvic pain (LBPP) after pregnancy in the present study (Q2) was defined as a positive response on the question as to whether the subject had actual low back pain or pelvic pain. The response alternatives to this question were 'yes, recurrent pain', 'yes, continuous pain' and 'no pain'. Fourteen women gave a time point at which LBPP had ceased; however, they also declared that they had since had recurrent pain. These subjects were allocated to the 'no pain' group.

Persistent LBPP after pregnancy included women with both 'recurrent pain' and 'continuous pain' defined as LBPP after pregnancy.

Breast feeding. The subjects were asked whether they were currently breast feeding and the status of the breast feeding (full-time or part-time). Subjects who were currently breast feeding part-time were asked to state the number of months they had previously practised full-time breast feeding. Those subjects who had previously breast-fed, but did not currently breastfeed, were asked to report the number of months they had practised breast feeding, both full-time and part-time. The method of calculating the periods of time for both types of breast feeding were as follows:

a) Currently breast feeding full-time. The period was calculated from the date of the delivery until the date when the questionnaire was filled in. It was assumed that the woman had breast-fed full-time throughout the period.

b) Currently breast feeding part-time. The period was calculated from the date of the delivery until the date when the questionnaire was filled in, minus the number of months of reported full-time breast feeding. 
c) Previously breast feeding full-time. The respondents stated the period of breast feeding in months.

d) Previous part-time breast feeding. The respondents stated the period of breast feeding in months.

Respondents were requested to report the periods of fulltime or part-time breast feeding in whole months, however, some subjects responded with both months and weeks. These responses were included with one week accounting for 0.25 months. Cases where the total period of reported breast feeding exceeded the individual's calculated postpartum period by one month or more were assessed individually. The reported number of months of full-time breast feeding was then accepted as being accurate (since full-time breast feeding usually precedes part-time breast feeding), and the period of part-time breast feeding was adjusted accordingly, resulting in a total time of breast feeding which did not exceed the postpartum period $(\mathrm{n}=18)$.

Body mass index (BMI) was defined as weight $(\mathrm{kg}) /$ height $^{2}(\mathrm{~m})$.

Parity was defined as number of births.

Oral contraception (OC) use. Respondents were requested to report whether they had used oral contraception during some period before the pregnancy, age at the start of OC use, and the total user-time of OC. If the respondent stated previous OC use she was requested to report whether she had used mainly combined OC (specified as 'combination of oestrogen and gestagen') or mainly 'mini-pills' (specified as 'only gestagen').

\section{Statistics}

Mean values and SD were calculated for parametric data. Differences between two groups were tested by independentsamples $t$-test and Pearson's chi-squared test for parametric and categorical data respectively. Odds ratios (OR) and their corresponding $95 \%$ confidence intervals (CI) were calculated by using logistic regression in univariate and multivariate analyses. Crude odds ratios (COR) were adjusted by maternal age, level of education, caesarean section, gestational age and smoking.

\section{Methodological Considerations}

Extensive discussions of the validity of the methods have been presented in previous publications [11, 31, 32]. In summary, the non-respondents did not differ from the respondents with regard to maternal age, gestational age, birthweight, mode of delivery, total experience of the delivery, epidural or spinal anaesthesia during delivery, or prepregnancy or end-pregnancy BMI. In the current study the non-respondents did not differ significantly from the respondents with regard to start of, user-time or type of oral contraception (OC), mean age at menarche, history of menstruations and regular smoking before pregnancy. However, nonrespondents had a significantly lower proportion of women who had used OC shorter or longer periods previous in life $(83.2 \%$ vs $91.8 \%$, p-value 0.002$)$ and included a higher proportion of women reporting smoking during pregnancy $(15.7 \%$ vs $6.5 \%$, p-value $<0.001)$.

The data are considered most probably representative for women with persistent LBPP after pregnancy. However, other unmeasured factors may have had influenced the results if they had been investigated.

\section{RESULTS}

\section{Breast Feeding}

A vast majority of the respondents had practised breast feeding for some period after delivery (95.3\%; Table 1). Almost $70 \%$ of the women were currently breast feeding at 6 months after delivery (Table 1). Full-time breast feeding was associated with an increased risk of continuous LBPP after delivery (p-value 0.014; COR 2.96 [1.21, 7.22]), and the OR was only slightly moderated when adjusted by maternal age, level of education, emergency CS, gestational age and smoking (OR 2.83 [1.12, 7.12]; Table 2). The longer the period of breast feeding, the greater the risk of continuous LBPP at 6 months postpartum (p-value 0.035, Table 1). Women with continuous pain also had a significantly longer total period of breast feeding in relation to women with remission of pain (p-value 0.044, Table 1).

\section{Oral Contraception}

Women with recurrent LBPP reported a history of OC use for some period in life to a higher extent than women with remission of LBPP (Table 3) and demonstrated an almost statistically significant increased risk (COR 2.24 [0.99, 5.07]) which became significant when adjusted by maternal age (OR 2.29 [1.01, 5.19]). In a multivariate logistic regression model the OR for recurrent LBPP was close to statistical significance when adjusted by maternal age, level of education, emergency CS, gestational age and smoking (OR $2.25[0.99,5.09]$. When all women with persistent pain (LBPP) were included in the analyses, the p-value became non-significant (0.071; corresponding COR 1.94 [0.93, 4.01]; Tables $\mathbf{2}$ and $\mathbf{3}$ ).

Age at the start of OC use, total user time of OC and type of OC did not reveal any association with risk of persistent LBPP after pregnancy (Table 3). Current use of OC did not differ between groups either (Table 3). Current OC was mainly low dosage gestagens. Mean time at start of current OC use was 3.1 months after delivery with a range of 1.0 to $6.0(\mathrm{n}=69 ;$ SD 1.3; Fig. 1).

\section{Menarche, Menstrual Pattern and Birthweight}

Women with persistent LBPP reported a significantly earlier menarche than women with remission of LBPP (12.6 yrs $v s 12.9$, p-value 0.048). History of menstrual pattern, and birthweight (Table 3) did not influence risk of persistent LBPP at six months postpartum.

\section{Smoking}

Regular smoking before pregnancy was reported by $18.4 \%$ of the respondents and the prevalence of smoking decreased during pregnancy (6.5\%). Smoking before or during pregnancy was not related to risk of persistent LBPP after pregnancy. Current smoking was at a level similar to that of pregnancy and was also not related to persistent LBPP (7.6\%).

\section{DISCUSSION}

The major finding in this study was that full-time breast feeding at six months after delivery was associated with an 
Table 1. Breastfeeding in Relation to the Different Sub-Groups of LBPP, 'No Pain', 'Recurrent Pain' and 'Continuous Pain'. Test of Difference Between the Sub-Groups ( $t$ Test for Parametric Data and Pearson's Chi-Square for Categorical Data)

\begin{tabular}{|c|c|c|c|c|c|c|c|}
\hline \multirow{2}{*}{ Variable } & \multirow{2}{*}{$\begin{array}{c}\text { All } \\
\text { Subjects }\end{array}$} & \multirow{2}{*}{$\begin{array}{l}\text { 1. No pain }{ }^{\mathrm{a}} \\
\text { (No) }\end{array}$} & \multirow{2}{*}{$\begin{array}{l}\text { 2. Recurrent } \\
\text { Pain (LBPP) } \\
\text { (No) }\end{array}$} & \multirow{2}{*}{$\begin{array}{c}\text { 3. Continuous } \\
\text { Pain (LBPP) }^{\mathrm{c}} \\
\text { (No) }^{\text {(No) }}\end{array}$} & \multicolumn{3}{|c|}{ P-Value ${ }^{d}$} \\
\hline & & & & & 1 vs 2 & 1 vs 3 & 1 vs $2+3$ \\
\hline $\begin{array}{l}\text { Number of subjects } \\
(\%)\end{array}$ & $\begin{array}{l}\mathbf{4 6 4} \\
(100.0)\end{array}$ & $\begin{array}{l}264 \\
(56.9)\end{array}$ & $\begin{array}{l}\mathbf{1 6 8} \\
(36.2)\end{array}$ & $\begin{array}{l}32 \\
(6.9)\end{array}$ & & & \\
\hline $\begin{array}{l}\text { Breast feeding (BF) some period } \\
\text { (No) } \\
\text { - yes: No }(\%) \\
\text { - no: No }(\%)\end{array}$ & $\begin{array}{l}(464) \\
\mathbf{4 4 2}(95.3) \\
\mathbf{2 2}(4.7)\end{array}$ & $\begin{array}{l}(264) \\
\mathbf{2 5 3}(95.8) \\
\mathbf{1 1}(4.2)\end{array}$ & $\begin{array}{l}(168) \\
\mathbf{1 5 9}(94.6) \\
\mathbf{9}(5.4)\end{array}$ & $\begin{array}{l}(32) \\
\mathbf{3 0}(93.8) \\
\mathbf{2}(6.2)\end{array}$ & 0.566 & 0.587 & 0.503 \\
\hline $\begin{array}{l}\text { Current BF (No) } \\
\text { - yes: No (\%) } \\
\text { - no: No (\%) }\end{array}$ & $\begin{array}{l}(463) \\
\mathbf{3 2 3}(69.8) \\
\mathbf{1 4 0}(30.2)\end{array}$ & $\begin{array}{l}(264) \\
\mathbf{1 8 0}(68.2) \\
\mathbf{8 4}(31.8)\end{array}$ & $\begin{array}{l}(167) \\
119(71.3) \\
48(28.7)\end{array}$ & $\begin{array}{l}(32) \\
\mathbf{2 4}(75.0) \\
\mathbf{8}(25.0)\end{array}$ & 0.500 & 0.431 & 0.394 \\
\hline $\begin{array}{l}\text { Current BF (No) } \\
\text { - Full-time BF No (\%) } \\
\text { - Part-time BF No (\%) }\end{array}$ & $\begin{array}{l}(323) \\
72(22.3) \\
\mathbf{2 5 1}(77.7)\end{array}$ & $\begin{array}{l}(180) \\
\mathbf{3 5}(19.4) \\
\mathbf{1 4 5}(80.6)\end{array}$ & $\begin{array}{l}(119) \\
27(22.7) \\
92(77.3)\end{array}$ & $\begin{array}{l}(24) \\
\mathbf{1 0}(41.7) \\
\mathbf{1 4}(58.3)\end{array}$ & 0.498 & 0.014 & 0.168 \\
\hline $\begin{array}{l}\text { Period of full-time BF (No) } \\
\text { Mean no of months } \\
\text { Range no of months }\end{array}$ & $\begin{array}{l}(414) \\
4.5 \\
0.25-8.0\end{array}$ & $\begin{array}{l}(238) \\
4.4 \\
0.25-7.4\end{array}$ & $\begin{array}{l}(148) \\
4.5 \\
0.5-7.0\end{array}$ & $\begin{array}{l}(28) \\
4.9 \\
0.5-8.0\end{array}$ & 0.224 & 0.035 & 0.084 \\
\hline $\begin{array}{l}\text { Period of part-time BF (No) } \\
\text { Mean no of months } \\
\text { Range no of months }\end{array}$ & $\begin{array}{l}(341) \\
1.7 \\
0.02-6.0\end{array}$ & $\begin{array}{l}(199) \\
\mathbf{1 . 7} \\
0.15-6.0\end{array}$ & $\begin{array}{l}(122) \\
\mathbf{1 . 7} \\
0.02-6.0\end{array}$ & $\begin{array}{l}(20) \\
\mathbf{2 . 1} \\
0.12-6.0\end{array}$ & 0.671 & 0.119 & 0.925 \\
\hline $\begin{array}{l}\text { Total period of BF (No) } \\
\text { Mean no of months } \\
\text { Range no of months }\end{array}$ & $\begin{array}{l}(442) \\
\mathbf{5 . 5} \\
0.25-8.9\end{array}$ & $\begin{array}{l}(253) \\
\mathbf{5 . 4} \\
0.25-8.9\end{array}$ & $\begin{array}{l}(159) \\
\mathbf{5 . 5} \\
0.5-8.0\end{array}$ & $\begin{array}{l}(30) \\
\mathbf{6 . 0} \\
3.5-8.0\end{array}$ & 0.738 & 0.044 & 0.339 \\
\hline
\end{tabular}

increased risk of continuous LBPP. Women with continuous pain also had a significantly longer total period of breast feeding in relation to women with remission of pain. This is the first publication reporting this relation and if this association proves stable, the counselling of pregnant women developing low back pain and pelvic pain during pregnancy should include information on the increased risk of persistence of LBPP at six months postpartum as a consequence of breast feeding. Since breast feeding is related to major positive health effects in the offspring both in a short-term and a long-term perspectives, as well as in the mother, counselling will prove a challenge if adequate information to the pregnant or breast feeding woman with LBPP is to be made available [20-23, 25].

Does 'prolonged' breast feeding respond to a causal mechanism resulting in an impaired remission of low back pain and pelvic pain after pregnancy? May breast feeding function as a confounder which is related both to the outcome under investigation and to an unknown factor which is the underlying cause of the impaired remission of LBPP? Is it feasible that women with more aggravating symptoms because of LBPP after pregnancy are more prone to breastfeed their children in comparison with women with remission of LBPP? In a study of duration of breast feeding in Swedish primiparous and multiparous women, smoking and breast milk supplementation without medical reasons influenced the duration of both exclusive and any breast feeding negatively, whereas early first breast feeding influenced the duration of both exclusive and any breast feeding positively, and parity had no significant influence [19]. In the same study higher maternal age influenced the duration of any breast feeding positively. It has previously been reported that the mean age of the subjects in the current study was significantly increased among women with recurrent pain (31.3 yrs), continuous pain (32.3 yrs) in comparison with women with remission of pain $(30.1 \mathrm{yrs})$, however there was no significant difference in parity (i.e. number of children) between groups [11]. The risk of continuous pain at six months after delivery was, however, only slightly moderated when adjusted by age.

These results indicate a potential new area of research, namely the possible role of prolactin on the prevalence of persistent LBPP after pregnancy. Pregnancy and lactation are periods of sustained physiological hyperprolactinemia, either through prolactin itself or placental lactogens [33]. The endocrine control of lactation is one of the most complex physiologic mechanisms of human parturition and oxytocin, serotonin, opioids, histamine, substance $\mathrm{P}$, and arginineleucine all modulate prolactin release by means of an autocrine/paracrine mechanism, whereas estrogen and progesterone can act at the hypothalamic and adenohypophysial levels [34]. High levels of progesterone inhibit lactation. 
Table 2. Odds Ratios (ORs) and their 95\% Confidence Intervals (CI) for the Subgroups of LBPP, 'Recurrent Pain', 'Continuous Pain', and 'Recurrent or Continuous Pain' in Relation to Specified Variables

\begin{tabular}{|c|c|c|c|c|c|c|c|}
\hline \multirow{2}{*}{ Variable } & \multirow{2}{*}{$\begin{array}{c}\text { No Pain } \\
\text { COR }\end{array}$} & \multicolumn{2}{|c|}{ Recurrent Pain (LBPP) ${ }^{b}$} & \multicolumn{2}{|c|}{ 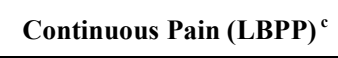 } & \multicolumn{2}{|c|}{ Recurrent or Continuous Pain (LBPP) } \\
\hline & & $\operatorname{COR}\left(n^{d}\right)$ & CI 95\% & $\operatorname{COR}\left(n^{d}\right)$ & CI $95 \%$ & $\operatorname{COR}\left(n^{d}\right)$ & CI $95 \%$ \\
\hline $\begin{array}{l}\text { Current full-time breast } \\
\text { feeding }\end{array}$ & 1.00 & $\begin{array}{l}1.21 \\
(299) \\
\end{array}$ & $0.69-2.15$ & $\begin{array}{l}2.96 \\
(204) \\
\end{array}$ & $1.21-7.22$ & $\begin{array}{l}1.45 \\
(323) \\
\end{array}$ & $0.85-2.45$ \\
\hline $\begin{array}{l}\text { OC use shorter or longer } \\
\text { periods previous in life }\end{array}$ & 1.00 & $\begin{array}{l}2.24 \\
(428) \\
\end{array}$ & $0.99-5.07$ & \begin{tabular}{|l|}
1.10 \\
$(295)$ \\
\end{tabular} & $0.31-3.88$ & $\begin{array}{l}1.94 \\
(460) \\
\end{array}$ & $0.93-4.01$ \\
\hline $\begin{array}{l}\text { Adjusted by maternal } \\
\text { age }^{\mathrm{g}}\end{array}$ & OR & $\begin{array}{l}\text { OR } \\
\left(n^{d}\right)\end{array}$ & CI 95\% & $\begin{array}{l}\text { OR } \\
\left(n^{d}\right)\end{array}$ & CI 95\% & $\begin{array}{l}\text { OR } \\
\left(n^{d}\right)\end{array}$ & CI 95\% \\
\hline $\begin{array}{l}\text { Current full-time breast } \\
\text { feeding }\end{array}$ & 1.00 & $\begin{array}{l}1.11 \\
(299) \\
\end{array}$ & $0.62-1.98$ & $\begin{array}{l}2.77 \\
(204) \\
\end{array}$ & $\begin{array}{l}1.12-6.83 \\
(204)\end{array}$ & $\begin{array}{l}1.31 \\
(323) \\
\end{array}$ & $0.76-2.24$ \\
\hline $\begin{array}{l}\text { OC use shorter or longer } \\
\text { periods previous in life }\end{array}$ & 1.00 & $\begin{array}{l}2.29 \\
(428) \\
\end{array}$ & $1.01-5.19$ & $\begin{array}{l}1.09 \\
(295) \\
\end{array}$ & $0.31-3.84$ & $\begin{array}{l}1.93 \\
(460) \\
\end{array}$ & $0.93-4.01$ \\
\hline $\begin{array}{l}\text { Adjusted by level of } \\
\text { education }\end{array}$ & OR & $\begin{array}{l}\text { OR } \\
\left(n^{d}\right)\end{array}$ & CI 95\% & $\begin{array}{l}\text { OR } \\
\left(n^{d}\right)\end{array}$ & CI 95\% & $\begin{array}{l}\text { OR } \\
\left(\mathbf{n}^{\mathrm{d}}\right)\end{array}$ & CI 95\% \\
\hline $\begin{array}{l}\text { Current full-time breast } \\
\text { feeding }\end{array}$ & 1.00 & $\begin{array}{l}1.16 \\
(298)\end{array}$ & $0.65-2.06$ & $\begin{array}{l}2.97 \\
(204) \\
\end{array}$ & $1.21-7.25$ & $\begin{array}{l}1.40 \\
(322)\end{array}$ & $0.82-2.38$ \\
\hline $\begin{array}{l}\text { OC use shorter or longer } \\
\text { periods previous in life }\end{array}$ & 1.00 & $\begin{array}{l}2.23 \\
(427)\end{array}$ & $0.98-5.04$ & $\begin{array}{l}1.11 \\
(295)\end{array}$ & $0.31-3.90$ & $\begin{array}{l}1.92 \\
(459)\end{array}$ & $0.93-3.99$ \\
\hline $\begin{array}{l}\text { Adjusted by caesarean } \\
\text { section }^{\mathrm{i}}\end{array}$ & OR & $\begin{array}{l}\text { OR } \\
\left(\mathbf{n}^{\mathrm{d}}\right) \\
\end{array}$ & CI 95\% & $\begin{array}{l}\text { OR } \\
\left(\mathbf{n}^{\mathrm{d}}\right)\end{array}$ & CI $95 \%$ & $\begin{array}{l}\text { OR } \\
\left(\mathbf{n}^{\mathrm{d}}\right) \\
\end{array}$ & CI 95\% \\
\hline $\begin{array}{l}\text { Current full-time breast } \\
\text { feeding }\end{array}$ & 1.00 & $\begin{array}{l}1.20 \\
(299) \\
\end{array}$ & $0.67-2.12$ & \begin{tabular}{|l|}
2.75 \\
$(204)$ \\
\end{tabular} & $1.09-6.89$ & $\begin{array}{l}1.40 \\
(323)\end{array}$ & $0.82-2.39$ \\
\hline $\begin{array}{l}\text { OC use shorter or longer } \\
\text { periods previous in life }\end{array}$ & 1.00 & $\begin{array}{l}2.22 \\
(428) \\
\end{array}$ & $0.98-2.22$ & $\begin{array}{l}1.05 \\
(295) \\
\end{array}$ & $0.29-3.71$ & $\begin{array}{l}1.90 \\
(460) \\
\end{array}$ & $0.91-3.95$ \\
\hline $\begin{array}{l}\text { Adjusted by emergency } \\
\text { caesarean section }\end{array}$ & OR & $\begin{array}{l}\text { OR } \\
\left(n^{d}\right)\end{array}$ & CI 95\% & $\begin{array}{l}\text { OR } \\
\left(n^{d}\right)\end{array}$ & CI 95\% & $\begin{array}{l}\text { OR } \\
\left(\mathbf{n}^{\mathrm{d}}\right)\end{array}$ & CI 95\% \\
\hline $\begin{array}{l}\text { Current full-time breast } \\
\text { feeding }\end{array}$ & 1.00 & $\begin{array}{l}1.22 \\
(299)\end{array}$ & $0.69-2.15$ & $\begin{array}{l}3.12 \\
(204) \\
\end{array}$ & $1.26-7.67$ & $\begin{array}{l}1.46 \\
(323)\end{array}$ & $0.86-2.47$ \\
\hline $\begin{array}{l}\text { OC use shorter or longer } \\
\text { periods previous in life }\end{array}$ & 1.00 & $\begin{array}{l}2.22 \\
(428) \\
\end{array}$ & $0.98-5.04$ & $\begin{array}{ll}1.11 \\
(295) \\
\end{array}$ & $0.31-3.88$ & $\begin{array}{l}1.92 \\
(460) \\
\end{array}$ & $0.92-3.99$ \\
\hline $\begin{array}{l}\text { Adjusted by gestational } \\
\text { age }^{\mathrm{k}}\end{array}$ & OR & $\begin{array}{l}\text { OR } \\
\left(\mathbf{n}^{\mathrm{d}}\right)\end{array}$ & CI 95\% & $\begin{array}{l}\text { OR } \\
\left(n^{d}\right)\end{array}$ & CI 95\% & $\begin{array}{l}\text { OR } \\
\left(\mathbf{n}^{\mathbf{d}}\right)\end{array}$ & CI $95 \%$ \\
\hline $\begin{array}{l}\text { Current full-time breast } \\
\text { feeding }\end{array}$ & 1.00 & $\begin{array}{l}1.21 \\
(299) \\
\end{array}$ & $0.68-2.13$ & $\begin{array}{ll}3.01 \\
(204) \\
\end{array}$ & $1.23-7.39$ & $\begin{array}{l}1.45 \\
(323) \\
\end{array}$ & $0.85-2.46)$ \\
\hline $\begin{array}{l}\text { OC use shorter or longer } \\
\text { periods previous in life }\end{array}$ & 1.00 & $\begin{array}{l}2.22 \\
(428) \\
\end{array}$ & $0.98-5.03$ & $\begin{array}{l}1.10 \\
(295) \\
\end{array}$ & $0.31-3.86$ & $\begin{array}{l}1.92 \\
(460) \\
\end{array}$ & $0.92-3.98$ \\
\hline $\begin{array}{l}\text { Adjusted by current smok- } \\
\text { ing }^{1}\end{array}$ & OR & $\begin{array}{l}\text { OR } \\
\left(n^{d}\right)\end{array}$ & CI $95 \%$ & $\begin{array}{l}\text { OR } \\
\left(n^{d}\right)\end{array}$ & CI $95 \%$ & $\begin{array}{l}\text { OR } \\
\left(n^{d}\right) \\
\end{array}$ & CI 95\% \\
\hline $\begin{array}{l}\text { Current full-time breast } \\
\text { feeding }^{\mathrm{e}}\end{array}$ & 1.00 & $\begin{array}{l}1.14 \\
(297)\end{array}$ & $0.64-2.04$ & $\begin{array}{l}2.88 \\
(203)\end{array}$ & $1.17-7.08$ & $\begin{array}{l}1.37 \\
(321)\end{array}$ & $0.80-2.33$ \\
\hline $\begin{array}{l}\text { OC use shorter or longer } \\
\text { periods previous in life }\end{array}$ & 1.00 & $\begin{array}{l}2.25 \\
(426)\end{array}$ & $0.99-5.09$ & $\begin{array}{l}1.11 \\
(294) \\
\end{array}$ & $0.31-3.89$ & $\begin{array}{l}1.93 \\
(458)\end{array}$ & $0.93-4.01$ \\
\hline $\begin{array}{l}\text { Adjusted by specified } \\
\text { variables }^{\mathrm{m}}\end{array}$ & OR & $\begin{array}{l}\text { OR } \\
\left(n^{d}\right)\end{array}$ & CI 95\% & $\begin{array}{l}\text { OR } \\
\left(n^{d}\right)\end{array}$ & CI 95\% & $\begin{array}{l}\text { OR } \\
\left(\mathbf{n}^{\mathbf{d}}\right)\end{array}$ & CI $95 \%$ \\
\hline $\begin{array}{l}\text { Current full-time breast } \\
\text { feeding }^{\mathbf{e}}\end{array}$ & 1.00 & $\begin{array}{l}1.01 \\
(296) \\
\end{array}$ & $0.55-1.82$ & $\begin{array}{l}2.83 \\
(203) \\
\end{array}$ & $1.12-7.12$ & $\begin{array}{l}1.21 \\
(320) \\
\end{array}$ & $0.70-2.20$ \\
\hline $\begin{array}{l}\text { OC use shorter or longer } \\
\text { periods previous in life }\end{array}$ & 1.00 & $\begin{array}{l}2.25 \\
(425)\end{array}$ & $0.98-5.11$ & $\begin{array}{l}1.10 \\
(294)\end{array}$ & $0.31-3.86$ & $\begin{array}{l}1.91 \\
(457)\end{array}$ & $0.91-3.97$ \\
\hline
\end{tabular}

a 'No pain' denotes respondents reporting cessation of LBPP.

b 'Recurrent pain' denotes respondents reporting recurrent LBPP after pregnancy.

c 'Continuous pain' denotes respondents reporting continuous LBPP after pregnancy.

${ }^{\text {d }}$ Number of subjects included in analysis.

${ }^{\text {e }}$ Reference group: current part-time breast feeding.

${ }^{\mathrm{f}}$ Reference group: no OC use previous in life.

${ }^{\mathrm{g}}$ Adjustment for maternal age, dichotomized; equal or below mean maternal age or above (mean age $30.7 \mathrm{yrs}$ ).

${ }^{\text {h }}$ Adjustment for education, dichotomized; below or above university level.

${ }^{i}$ Adjustment for caesarean section (CS), dichotomized; CS or vaginal delivery.

${ }^{j}$ Adjustment for emergency caesarean section (CS); emergency CS or vaginal delivery or elective CS

${ }^{\mathbf{k}}$ Adjustment for gestational age, dichotomized; less than 37 weeks of gestation or longer.

${ }^{1}$ Adjustment for current smoking, dichotomized; current smokning or no current smoking.

${ }^{\mathrm{m}}$ Multivariate model with adjustment for maternal age, education, emergency CS, gestational age and smoking. 
Table 3. History of Oral Contraception Use (OC) and Birthweight in Relation to the Different Sub-Groups of LBPP, 'No Pain', 'Recurrent Pain' and 'Continuous Pain'. Test of Difference Between the Sub-Groups ( $t$ Test for Parametric Data and Pearson's Chi-Square for Categorical Data)

\begin{tabular}{|c|c|c|c|c|c|c|c|}
\hline \multirow{2}{*}{ Variable } & \multirow{2}{*}{ All Subjects } & \multirow{2}{*}{$\begin{array}{l}\text { 1. No Pain }{ }^{\mathrm{a}} \\
\text { (No) }\end{array}$} & \multirow{2}{*}{$\begin{array}{l}\text { 2. Recurrent } \\
\text { Pain (LBPP) } \\
\quad(\text { No) }\end{array}$} & \multirow{2}{*}{$\begin{array}{l}\text { 3. Continuous } \\
\text { Pain (LBPP) } \\
\text { (No) }\end{array}$} & \multicolumn{3}{|c|}{ P-Value ${ }^{d}$} \\
\hline & & & & & 1 vs 2 & 1 vs 3 & 1 vs $2+3$ \\
\hline $\begin{array}{l}\text { Number of subjects } \\
(\%)\end{array}$ & $\begin{array}{l}464 \\
(100.0)\end{array}$ & $\begin{array}{l}264 \\
(56.9)\end{array}$ & $\begin{array}{l}\mathbf{1 6 8} \\
(36.2)\end{array}$ & $\begin{array}{l}32 \\
(6.9)\end{array}$ & & & \\
\hline $\begin{array}{l}\text { OC use shorter or longer periods } \\
\text { previous in life }\left(\mathbf{Q 1}^{\mathrm{e}}\right)(\mathrm{No}) \\
\text { - yes: No }(\%) \\
\text { - no: No }(\%)\end{array}$ & $\begin{array}{l}(460) \\
\mathbf{4 2 2}(91.7) \\
\mathbf{3 8}(8.3)\end{array}$ & $\begin{array}{l}(263) \\
\mathbf{2 3 6}(89.7) \\
\mathbf{2 7}(10.3)\end{array}$ & $\begin{array}{l}(165) \\
157(95.2) \\
\mathbf{8}(4.8)\end{array}$ & $\begin{array}{l}(32) \\
\mathbf{2 9}(90.6) \\
\mathbf{3}(9.4)\end{array}$ & 0.047 & 0.875 & 0.071 \\
\hline $\begin{array}{l}\text { Start of } \mathrm{OC}(\mathrm{Q} 1)(\mathrm{No}) \\
\text { - mean age }(\mathrm{yrs}) \\
\text { - range (yrs) } \\
\text { - SD (yrs) }\end{array}$ & $\begin{array}{l}(423) \\
\mathbf{1 7 . 5} \\
10-32 \\
2.9\end{array}$ & $\begin{array}{l}(235) \\
\mathbf{1 7 . 5} \\
10-32 \\
3.0\end{array}$ & $\begin{array}{l}(159) \\
\mathbf{1 7 . 6} \\
13-31 \\
2.9\end{array}$ & $\begin{array}{l}(29) \\
17.3 \\
14-22 \\
2.0\end{array}$ & 0.653 & 0.750 & 0.757 \\
\hline $\begin{array}{l}\text { User time of OC (Q1) (No) } \\
\text { - mean no (yrs) } \\
\text { - range (yrs) } \\
\text { - SD (yrs) }\end{array}$ & $\begin{array}{l}(420) \\
\mathbf{6 . 0} \\
0.1-22 \\
3.9\end{array}$ & $\begin{array}{l}(235) \\
6.2 \\
0.1-20 \\
3.8\end{array}$ & $\begin{array}{l}(157) \\
\mathbf{5 . 8} \\
0.1-22 \\
3.9\end{array}$ & $\begin{array}{l}(28) \\
\mathbf{5 . 9} \\
0.5-17.0 \\
4.1\end{array}$ & 0.307 & 0.756 & 0.317 \\
\hline $\begin{array}{l}\text { Type of OC (Q1) (No; \%) } \\
\text { - mainly combined OC: No (\%) } \\
\text { - mainly mini-pills: No (\%) } \\
\text { - don't know: No (\%) }\end{array}$ & $\begin{array}{l}(424) \\
\mathbf{2 9 3}(69.1) \\
\mathbf{5 1}(12.0) \\
\mathbf{8 0}(18.9)\end{array}$ & $\begin{array}{l}(237) \\
162(68.4) \\
29(12.2) \\
\mathbf{4 6}(19.4)\end{array}$ & $\begin{array}{l}(158) \\
\mathbf{1 1 0}(69.6) \\
\mathbf{1 8}(11.4) \\
\mathbf{3 0}(19.0)\end{array}$ & $\begin{array}{l}(29) \\
\mathbf{2 1}(72.4) \\
\mathbf{4}(13.8) \\
\mathbf{4}(13.8)\end{array}$ & 0.957 & 0.761 & 0.929 \\
\hline $\begin{array}{l}\text { Current use of } \mathrm{OC}\left(\mathrm{Q2}^{\mathrm{f}}\right)(\mathrm{No}) \\
\text { - yes: No (\%) } \\
\text { - no: No }(\%)\end{array}$ & $\begin{array}{l}(460)^{\mathrm{e}} \\
\mathbf{7 1}(15.4) \\
\mathbf{3 8 9}(84.6)\end{array}$ & $\begin{array}{l}(263) \\
45(17.1) \\
218(82.9)\end{array}$ & $\begin{array}{l}(165) \\
\mathbf{2 4}(14.5) \\
\mathbf{1 4 1}(85.5)\end{array}$ & $\begin{array}{l}(32) \\
\mathbf{2}(6.3) \\
\mathbf{3 0}(93.8)\end{array}$ & 0.482 & 0.113 & 0.250 \\
\hline $\begin{array}{l}\text { Birthweight }(\mathbf{Q 1})(\mathrm{No}) \\
\text { Mean weight in grams } \\
\text { Weight range in grams } \\
\text { SD in grams }\end{array}$ & $\begin{array}{l}(464) \\
3567 \\
1054-5620 \\
652\end{array}$ & $\begin{array}{l}(264) \\
3567 \\
1054-5120 \\
686\end{array}$ & $\begin{array}{l}(168) \\
3663 \\
1376-5620 \\
595\end{array}$ & $\begin{array}{l}(32) \\
3497 \\
1555-4515 \\
647\end{array}$ & 0.136 & 0.585 & 0.256 \\
\hline
\end{tabular}

After delivery of placenta, progesterone and estrogen levels fall over 5 to 6 days, and in addition, prolactin levels also decline over 2 to 3 weeks postpartum if the breasts are not stimulated [35]. Lactation functions on a supply-demand basis, and infant suckling is the key event of breast feeding [35]. Serum prolactin levels and the prolactin response to suckling remain higher in fully breast feeding women who remain amenorrhoic for at least 180 days postpartum compared with fully breast feeding women who are not amenorrhoic [35]. It has previously been reported that some period of amenorrhoea not related to pregnancy is a risk factor for LBPP during pregnancy [6]. Bone density decreases during pregnancy and lactation, and whilst this decrease has not been found to be associated with back and pelvic pain during pregnancy, the study was not conclusive as to whether loss of bone density was associated with back and pelvic pain during lactation [36].

A history of OC use for some period in life was found to be associated with an increased risk of recurrent LBPP (pvalue 0.047 ). In a multivariate regression model the doubled
OR for recurrent LBPP almost reached statistical significance. However, when all women with persistent LBPP were included in the analyses, they became non-significant. A previous Swedish study indicates that non- or short term users of OC have an increased risk of persistent pain after delivery compared to long term users [27]. In this study, age at start of OC use, total user time of OC and type of OC did not reveal any association with risk of persistent LBPP after pregnancy. The findings are therefore contradictory. There are currently very few studies investigating the effect of previous OC use on the risk of persistent pain after pregnancy and the issue whether OC use is associated with persistent pain after pregnancy must be currently considered unsolved. Biologically, it seems plausible that steroid hormones may influence the risk of LBPP during pregnancy and persistent LBPP after pregnancy, since pregnancy is a highlevel steroid hormonal condition.

Current OC use did not reveal any association with persistent LBPP. The mean start time was 3.1 months after delivery, which means that half of the group of OC users had 


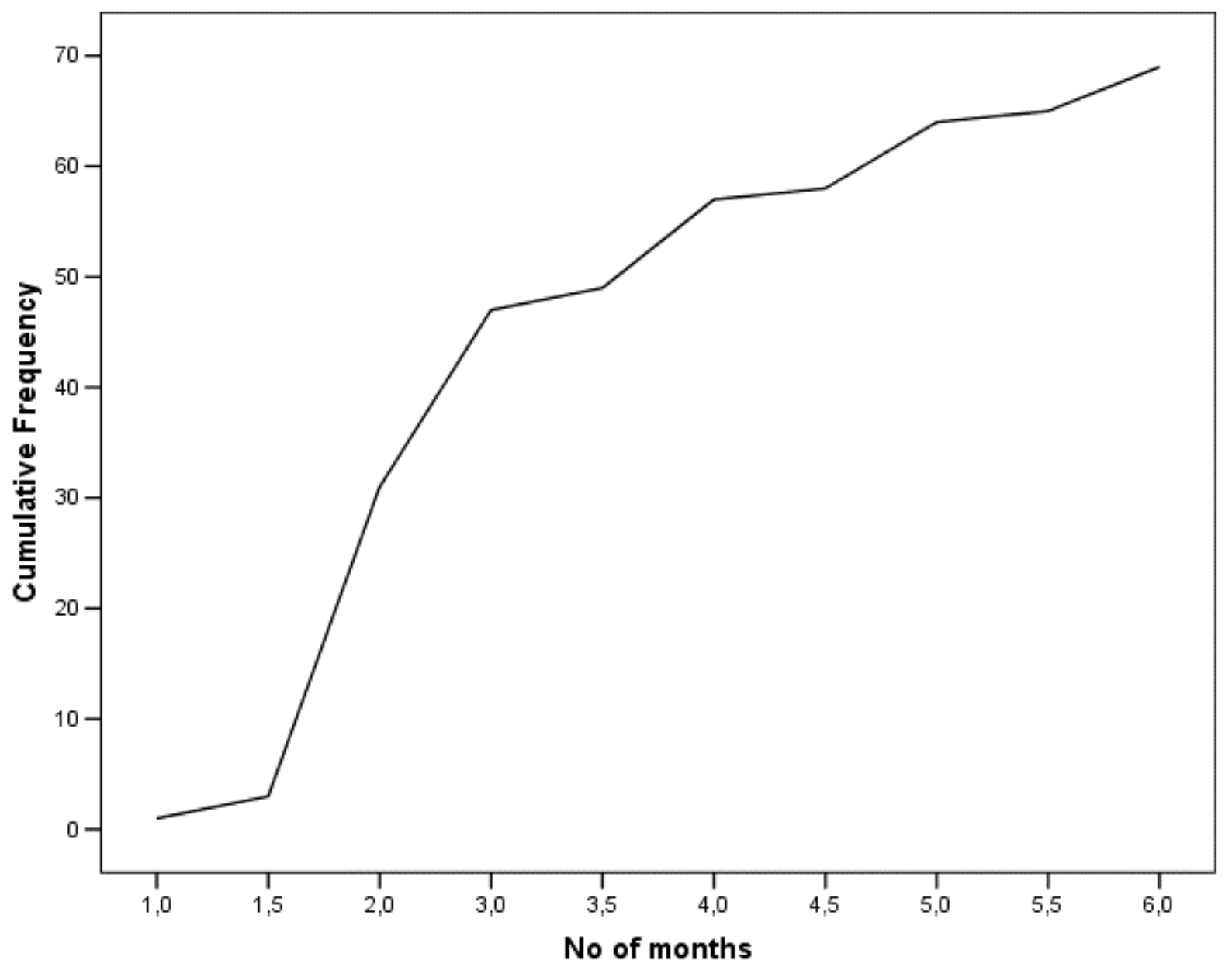

Fig. (1). Mean time (months) at start of current OC use postpartum.

less than 3.1 months of exposure to mostly gestagens. From a long-term perspective, current OC use may be one of several negative factors to influence the risk of persistent LBPP, however this theory would require a longer follow-up period for validation. Contraception choices may be limited for lactating women, due to concerns about hormonal effects on quality and quantity of milk, passage of hormones to the infant and infant growth [37]. A systematic review of randomized controlled trials on contraception during lactation concludes that there is limited evidence on the effect of hormonal contraceptives on lactation [37].

Women with persistent LBPP reported a significantly earlier menarche than women with remission of LBPP which is consistent with a previous finding in a Norwegian study, where women with persistent pelvic pain and pelvic joint instability were characterized by a significantly lower age at menarche [29]. Progesterone concentrations among women reporting pelvic pain during pregnancy have been found significantly higher at gestational age 6 to 12 weeks, however, there was no association found between progesterone levels later in pregnancy and pelvic pain [38]. Oestradiol concentrations did not show an association with pelvic pain during pregnancy in the same study. Oestrogen and progesterone may have primary roles in the causal paths of LBPP both during and after pregnancy, such as programming resulting in predisposition of LBPP.
The methodological considerations has been reported in the method section.

\section{CONCLUSION}

Full-time breast feeding and longer period of breast feeding were positively associated with persistent low back and pelvic pain six months after delivery. This is the first study reporting this association and therefore these results needs to be confirmed by future studies.

\section{ACKNOWLEDGEMENTS}

The author would like to thank all participating women sharing their obstetric history and experiences during and after pregnancy. This study was supported by grants from the County Council of Västerbotten, the Joint Committee of the Northern Sweden Health Care Region, and the Medical Faculty, Umeå University.
ABBREVIATIONS
Q1 $=$ The first questionnaire after delivery
Q2 $=$ The second questionnaire at approximately six months after delivery
COR = Crude odds ratio
$O R=$ Odds ratio
$S D=$ Standard deviation 
$C I=$ Confidence interval

UNICEF $=$ The United Nations Children's Fund

MRI = Magnetic resonance imaging

\section{REFERENCES}

[1] Berg G, Hammar M, Moller-Nielsen J, Linden U, Thorblad J. Low back pain during pregnancy. Obstet Gynecol 1988; 71: 71-5.

[2] Fast A, Shapiro D, Ducommun EJ, Friedmann LW, Bouklas T, Floman Y. Low-back pain in pregnancy. Spine 1987; 12: 368-71.

[3] Ostgaard HC, Andersson GB, Karlsson K. Prevalence of back pain in pregnancy. Spine 1991; 16: 549-52.

[4] Kristiansson P, Svardsudd K, von Schoultz B. Back pain during pregnancy: a prospective study. Spine 1996; 21(6): 702-9.

[5] Mens JM, Vleeming A, Stoeckart R, Stam HJ, Snijders CJ. Understanding peripartum pelvic pain: implications of a patient survey. Spine 1996; 21: 1363-9; discussion 9-70.

[6] Mogren IM, Pohjanen AI. Low back pain and pelvic pain during pregnancy: prevalence and risk factors. Spine 2005; 30: 983-91.

[7] Larsen EC, Wilken-Jensen C, Hansen A, et al. Symptom-giving pelvic girdle relaxation in pregnancy. I: Prevalence and risk factors. Acta Obstet Gynecol Scand 1999; 78: 105-10.

[8] Ostgaard HC, Andersson GB. Postpartum low-back pain. Spine 1992; 17: 53-5.

[9] Ostgaard HC, Roos-Hansson E, Zetherstrom G. Regression of back and posterior pelvic pain after pregnancy. Spine 1996; 21:2777-80.

[10] Turgut F, Turgut M, Cetinsahin M. A prospective study of persistent back pain after pregnancy. Eur J Obstet Gynecol Reprod Biol 1998; 80: 45-8.

[11] Mogren IM. BMI, pain and hyper-mobility are determinants of long-term outcome for women with low back pain and pelvic pain during pregnancy. Eur Spine J 2006; 15: 1093-102.

[12] Nilsson-Wikmar L, Pilo C, Pahlback M, Harms-Ringdahl K. Perceived pain and self-estimated activity limitations in women with back pain post-partum. Physiother Res Int 2003; 8: 23-35.

[13] Noren L, Ostgaard S, Johansson G, Ostgaard HC. Lumbar back and posterior pelvic pain during pregnancy: a 3-year follow-up. Eur Spine J 2002; 11:267-71.

[14] Wu WH, Meijer OG, Uegaki K, et al. Pregnancy-related pelvic girdle pain (PPP), I: Terminology, clinical presentation, and prevalence. Eur Spine J 2004; 27: 575-89.

[15] Schauberger CW, Rooney BL, Goldsmith L, Shenton D, Silva PD, Schaper A. Peripheral joint laxity increases in pregnancy but does not correlate with serum relaxin levels. Am J Obstet Gynecol 1996; 174: 667-71.

[16] Paul JA, van Dijk FJ, Frings-Dresen MH. Work load and musculoskeletal complaints during pregnancy. Scand J Work Environ Health 1994; 20: 153-9.

[17] Hansen A, Jensen DV, Larsen EC, et al. Postpartum pelvic pain-the "pelvic joint syndrome": a follow-up study with special reference to diagnostic methods. Acta Obstet Gynecol Scand 2005; 84: $170-6$.

[18] Hofvander Y. Breastfeeding and the baby friendly hospitals initiative (BFHI): organization, response and outcome in Sweden and other countries. Acta Paediatr 2005; 94: 1012-6.

[19] Ekstrom A, Widstrom AM, Nissen E. Duration of breastfeeding in Swedish primiparous and multiparous women. J Hum Lact 2003; 19: $172-8$.
[20] Oddy WH. The impact of breastmilk on infant and child health. Breastfeed Rev 2002; 10: 5-18.

[21] Schack-Nielsen L, Larnkjaer A, Michaelsen KF. Long term effects of breastfeeding on the infant and mother. Adv Exp Med Biol 2005; 569: 16-23.

[22] Martin RM, Smith GD, Mangtani P, Frankel S, Gunnell D. Association between breast feeding and growth: the Boyd-Orr cohort study. Arch Dis Child Fetal Neonatal Ed 2002; 87: F193-201.

[23] Martin RM, Ebrahim S, Griffin M, et al. Breastfeeding and atherosclerosis: intima-media thickness and plaques at 65-year follow-up of the Boyd Orr cohort. Arterioscler Thromb Vasc Biol 2005; 25: 1482-8.

[24] Martin RM, Gunnell D, Smith GD. Breastfeeding in infancy and blood pressure in later life: systematic review and meta-analysis. Am J Epidemiol 2005; 161: 15-26.

[25] Riman T, Nilsson S, Persson IR. Review of epidemiological evidence for reproductive and hormonal factors in relation to the risk of epithelial ovarian malignancies. Acta Obstet Gynecol Scand 2004; 83: 783-95.

[26] Brynhildsen J, Lennartsson H, Klemetz M, Dahlquist P, Hedin B, Hammar M. Oral contraceptive use among female elite athletes and age-matched controls and its relation to low back pain. Acta Obstet Gynecol Scand 1997; 76: 873-8.

[27] Bjorklund K, Nordstrom ML, Odlind V. Combined oral contraceptives do not increase the risk of back and pelvic pain during pregnancy or after delivery. Acta Obstet Gynecol Scand 2000; 79: 97983.

[28] Wreje U, Isacsson D, Aberg H. Oral contraceptives and back pain in women in a Swedish community. Int J Epidemiol 1997; 26: 714.

[29] Saugstad LF. Is persistent pelvic pain and pelvic joint instability associated with early menarche and with oral contraceptives? [see comments]. Eur J Obstet Gynecol Reprod Biol 1991; 41: 203-6.

[30] Latthe P, Mignini L, Gray R, Hills R, Khan K. Factors predisposing women to chronic pelvic pain: systematic review. BMJ 2006; 332: 749-55.

[31] Mogren IM. Does caesarean section negatively influence the postpartum prognosis of low back pain and pelvic pain during pregnancy? Eur Spine J 2007; 16(1): 115-21. Epub 2006 May 5.

[32] Mogren I. Perceived health at six months after delivery in women who have experienced low back pain and pelvic pain during pregnancy. Scand J Caring Sci 2007; In press.

[33] Andrews ZB. Neuroendocrine regulation of prolactin secretion during late pregnancy: easing the transition into lactation. J Neuroendocrinol 2005; 17: 466-73.

[34] Buhimschi CS. Endocrinology of lactation. Obstet Gynecol Clin North Am 2004; 31: 963-79, xii.

[35] Hill PD, Chatterton RT, Jr, Aldag JC. Serum prolactin in breastfeeding: state of the science. Biol Res Nurs 1999; 1: 65-75.

[36] Bjorklund K, Naessen T, Nordstrom ML, Bergstrom S. Pregnancyrelated back and pelvic pain and changes in bone density. Acta Obstet Gynecol Scand 1999; 78: 681-5.

[37] Truitt ST, Fraser AB, Grimes DA, Gallo MF, Schulz KF. Hormonal contraception during lactation. systematic review of randomized controlled trials. Contraception 2003; 68: 233-8.

[38] Kristiansson P, Svardsudd K, von Schoultz B. Reproductive hormones and aminoterminal propeptide of type III procollagen in serum as early markers of pelvic pain during late pregnancy. Am J Obstet Gynecol 1999; 180: 128-34. 